First Peoples Child \& Family Review

An Interdisciplinary Journal Honouring the Voices, Perspectives, and Knowledges of First Peoples through Research, Critical Analyses, Stories, Standpoints and Media Reviews

\title{
Voices of Students: We are Here! We are Ready to Care for the Next Generations! "Gathering \& Sharing Wisdom Conference” and the Indigenous Child Welfare Research Network
}

\author{
Jacquie Green, Rebecca Taylor, Rakiva Larken, Margaret Brier and Trevor \\ Good
}

Volume 5, Number 1, 2010

URI: https://id.erudit.org/iderudit/1069058ar

DOI: https://doi.org/10.7202/1069058ar

See table of contents

Publisher(s)

First Nations Child and Family Caring Society of Canada

ISSN

1708-489X (print)

2293-6610 (digital)

Explore this journal

Cite this article

Green, J., Taylor, R., Larken, R., Brier, M. \& Good, T. (2010). Voices of Students: We are Here! We are Ready to Care for the Next Generations! "Gathering \& Sharing Wisdom Conference" and the Indigenous Child Welfare Research Network. First Peoples Child \& Family Review, 5(1), 15-21.

https://doi.org/10.7202/1069058ar

\section{Article abstract}

This paper highlights the voices of four youth presenters at the first "Gathering and Sharing Conference" hosted onCoast Salish Territory, Songhees and Esquimalt, in Victoria, British Columbia. You will be guided through story about our role as leaders, planners, and facilitators for this conference which was convened to provide a central space for Indigenous youth and other community members to share stories about the caring and nurturing of our children, families and communities.
Copyright ( ) Jacquie Green, Rebecca Taylor, Rakiva Larken, Margaret Brier, Trevor Good, 2010
This document is protected by copyright law. Use of the services of Érudit (including reproduction) is subject to its terms and conditions, which can be viewed online.

https://apropos.erudit.org/en/users/policy-on-use/ 


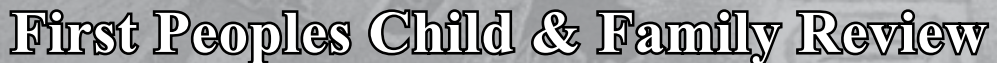

An Interdisciplinary Journal Honoring the Voices, Perspectives and Knowledges of First

Peoples through Research, Critical Analyses, Stories, Standpoints and Media Reviews

\section{Voices of Students: We are Here! We are Ready to Care for the Next Generations! "Gathering \& Sharing Wisdom Conference" and the Indigenous Child Welfare Research Network}

\author{
Jacquie Green ${ }^{\mathrm{a}}$, Rebecca Taylor ${ }^{\mathrm{b}}$, Rakiva Larken ${ }^{\mathrm{c}}$, Margaret Brier ${ }^{\mathrm{d}}$ and Trevor Good ${ }^{\mathrm{e}}$
}

a Jacquie Green is from the Haisla Nation. She is Associate Professor in the School of Social Work and holds a BSW, MPA, and is currently working on a PhD. She is Project Manager for Indigenous Child Welfare Research Network. She is committed to decolonization and cultural renewal; her research interests involve strategizing curriculum, programs and policies that center Indigenous philosophies and values. Her current research is on reclaiming Haisla ways through Oolichan Fishing.

b Rebecca Taylor is a Graduate Research Assistant for Indigenous Child Welfare Research Network. She is a mother and Masters Student in the Indigenous Social Work Program at the University of Victoria. She is Inupiaq from the Bering Straits Region of Alaska and was raised in Northern BC in Smithers.

c Rakiya Larken is Namgis and Piikani First Nation. She is a grade 11 student, an HIV AIDS and children's rights activist and has presented at numerous conferences across Canada about issues facing young First Nations girls. Through Anti-dote Multiracial Girlz and Women's Network she has created a short film, "The Silent Epidemic" to help raise awareness and questions about how HIVIAIDS is addressed in the school system. See: http://www.youtube.com/watch?v=hg2cxwjJkms

d Margaret Briere is from the Coast Salish territory of Shishalh (Sechelt) Nation. On her mother's side she is from the Coast Salish territory of Shishalh (Sechelt) Nation. On her father's side, she is from Nanaimo BC of European decent-French Canadian. Currently, she is attending the University of Victoria, and taking Child and Youth Care courses.

e Trevor Good is Coast Salish, from the Snuneymuxw Nation. He is a recent graduate of a Bachelor of Social Work, First Nations Specialization. $\mathrm{He}$ is also a graduate of the Indigenous Studies Program (formerly the First Nations Community Studies Program) offered at Camosun College. Trevor has worked at the Victoria Native Friendship Centre for two years in different roles all of which were great learning experiences. He is grateful for working with the Office of Indigenous Affairs and continue to being in a role as a helper for the Indigenous community at the University of Victoria. HISWKE, Huy ch q'u, Gilakas'la, Kleco Kleco!

Questions or correspondence concerning this article may be addressed to:

Jacquie Green

Phone: 250.721.6453

Fax: 250.721.6288

jlgreen@uvic.ca

\begin{abstract}
This paper highlights the voices of four youth presenters at the first "Gathering and Sharing Wisdom Conference" hosted on Coast Salish Territory, Songhees and Esquimalt, in Victoria, British Columbia. You will be guided through story about our role as leaders, planners, and facilitators for this conference which was convened to provide a central space for Indigenous youth and other community members to share stories about the caring and nurturing of our children, families and communities.
\end{abstract}

\section{Leading up to the Conference}

Over the last year we delivered two training sessions in British Columbia on the topic of Indigenous Research. The sessions were carried out in the format of an interactive workshop over the course of two days and were designed as a skill sharing resource for those working in Indigenous child welfare research and practice as well as for Indigenous people for whom these topics are pertinent. Some of the stated goals of the training sessions were to: highlight projects and practices that are working; to share resources, skills and to provide a forum for networking; to examine contentious histories with regards to research on Indigenous peoples; and finally, to examine more current Indigenous directed research projects and Indigenous methodologies within research.

Our approach to training was very similar to our conference planning. Prior to training we met with the local community, young people and Elders. We planned with them what the training could look like in their community. The young people in both venues spoke to the audience about what was important to them. They shared about how they (the young people) are living their lives differently and let us know what was important for them to resist life challenges as Indigenous young people. In our training sessions the young people shared that social 
Note:

Our Indigenous Child Welfare Research Network is very new; we have been in operation since October 2008. Ultimately, our goal is to provide support to Indigenous communities and organizations to meet their own research needs. Importantly, given the diversity among Indigenous peoples in British Columbia, our network strives to be inclusive of various Indigenous knowledges and practices.

workers make to many assumptions about young Indigenous people. They said that not all young people skip school, not all young people drink or do drugs, not all young people run away from home. The young people also shared that they are often told that they are to respect all living things; yet, they see adults been cruel to animals, to the land and to other people. They asked what message are these actions of adults to young people. As conference organizers we wanted to create space for young people to share their knowledge at this provincial forum about what is important for them. We invited several young people to share what was important for them to say to adults, educators, social workers and our communities. The young people who were invited came from many different aspects of life. Some were pursuing post secondary education; one young person was in high school and another young person was a young mom. This paper highlights the voice of the young people who gracefully accepted our invitation to speak at our Gathering and Sharing Wisdom conference.

In early 2009 our project team began planning for our first Research Network conference. This conference would be a province wide and large gathering, the first of its kind on the topic of Indigenous Child Welfare Research Network in BC, organized by and from Indigenous people and perspectives. It was clear from our organizing team that there was a need to incorporate student and youth voices throughout the two day conference. One of the goals of our network is to link the voices of young people into the work that we do as professionals, researchers, academics and care takers from our different communities. In our training sessions and our conference we wanted to ensure that the voices of young people were present at the onset of planning, implementing our conference agenda. As conference organizers we remembered voices of our leaders who say that their decisions are for the next seven generations. We wanted the young people to be at the forefront with leaders to illustrate that indeed they will be mentored to be our future leaders.

Once our training was completed, we quickly moved into planning for our first annual "Gathering \& Sharing Wisdom Conference" October 6 \& 7, 2009. Once again our goal was to centre Indigenous stories and knowledge through voices from our Elders, Post Secondary Students, Young people and Youth1. We invited Chief Wayne Christian and Cindy Blackstock, two

1. We recognize and acknowledge that young people can be identified in various ways. We have identified three categories. We invited young students who are Post Secondary students; we invited a young Mom who was 24 years old and one youth who is in high school.
Indigenous leaders from British Columbia to be our key note speakers. We then asked that they share the key note space with a young person and/or a post secondary student.

It was important in our planning to invite special guests and as such we invited local communities, Elders and various dignitaries from different Indigenous organizations and governments in $\mathrm{BC}$. In preparation we also met regularly with Elders Voices, an important program hosted through the Office of Indigenous Affairs at the University of Victoria. Led by Elders from several Nations, this honoured group helps to lead ceremonies, protocol and take part in the "Elders in Residence" program on campus in which they alternate days spent in the Elders' Lounge, at the First People's House, providing guidance and support for students and staff at the university. Through our organization development and planning for the conference, Elders' Voices has been an advisory group to our project.

We also met with young people to ensure that our approach to centering young voices was done in a respectful manner. We held two meetings where Elders Voices and the young people were introduced to one another as well as additional organizing meetings for the conference planning team, volunteers, youth, Elders and staff. Thus the hosting of the conference was a collaboration of local people, Elders, young people and our steering committee members.

\section{Selection of Speakers}

Early in the conference planning stages we sought out Indigenous students from the University of Victoria to ask them if they were interested in speaking at the conference. We did this because we felt it was important to include student voices, given the nature of the conference and it's affiliation with the University. Some were unsure, some didn't think they could speak in a conference setting and some said 'sure', but not really sure of the expectation. We invited speakers who we met on campus or in the community. There were recommendations to invite students who were known for their activism, contribution to learning cultural ways and educational accomplishments.

As the conference date drew closer we had 24 different workshop presentations selected. Presenters spoke about the storytelling (research) they are doing in their communities. Some spoke about policies and laws they are working on. Others spoke about their experiences as government and educational researchers. On day two the keynote speech for 
the day was entitled "4 generations" involving Elder Ray Green, his daughter Jacquie Green, his granddaughter Rosie Woods and his Great Granddaughter Nizhonie. The organizers wanted to illustrate four generations where learning and healing took place in a family. Ray is a residential school survivor and because of the abuse he endured in the school, he did not want to teach his children Haisla language or teachings. He shared how he and his wife have been working through their trauma from residential school and how they are now teaching their children, grand children and Great Grandchildren. Elders in the conference appreciated the words Ray shared, as his story was similar to their story. Younger people thanked Ray and family for sharing their story in an honest way.

To begin our conference it was important for us to honor the local territories and their cultural practices. We invited a local Elder, a member of our steering committee and the young artist who did our project logo to welcome participants, share in words, encouragement and prayer. ${ }^{2}$ The artist, Dylan Thomas, explained the logo design, "I have used human hands to symbolize the helping hand of the organization. The hands and arms wrap around the ravens (symbolizing children) to portray the protection that will be provided by the organization. I chose ravens to represent the children because in Salish mythology ravens are symbols of changes in life and transformation, which I thought would be a perfect representation for what the Indigenous Child Welfare Research Project does."

On day one of the conference we highlighted student voices and young people. The words they had to share with participants and the energy they provided to our conference environment was invigorating and profound. The young voices at the onset set the tone for two days and as such throughout the two days of presenters centered young people, connected young people to their practices culturally and professionally.

In total, all speakers alluded to the importance of 'gathering sharing wisdom.' To keep with our momentum in centering young people, rather than provide participants with conference bags, we provided them with 'youthful' back packs and asked that they give their back pack to a young

2 The local Elders, Joyce and Victor Underwood are from Tsawout First Nations; Robina Thomas and her son Dylan are Lyackson - all from within the Coast Salish Territory person in their community. Our idea to ask participants to gift young people in their community was to promote the idea of 'gifting'. Participants were able to gather with other Indigenous communities to share and gather knowledge which is rewarding to each participant. We wanted to remind participants to think of young people in their community or organization who could not experience in this event of sharing stories and wisdom. We asked participants to gift a young person with their back pack and let the young person know that 
wonderful territory we reside on. Once participants were settled and waiting to 'share and gather wisdom' we then introduced the young voices beginning with Rakiya. Here is what she had to say:

\section{I am a proud First Nation's youth. Everyone here has enough knowledge to know we are not equally treated as others are. We need help in this fight for our rights and freedom. Collectively we have to come together, and stand up to those who have tried to knock us down. We are not stupid we are not powerless we are the voice to push for- ward. Words are an expression of oneself they can destroy and also give life. We as Indigenous people have seen both sides of the spectrum. As a race we must rewrite the poli- cies as Harper and John A MacDonald rewrote our HIS- TORY. We must be the voices for ones who can't speak for themselves. It is vital to our souls to embrace support and love our children and youth. The youth I see today simply need someone to listen. They don't want money, they don't want fame and most importantly they don't want to be anyone's problem, they just need someone to listen. So as a First Nations youth I ask you all to go home and just listen to our youth and children because we will always be here we will always stand together in unity. The government can try to shove us to the side, they can try to put us under the carpet but SORRY they are wasting their time we were here in the beginning and we will be here till the end. The time is now for change -- I march for my people! What do you march for?}

Thank you to Rakiya for welcoming participants to our conference. Your energy is vibrant, your knowledge about Indigenous history is incredible and the words you shared to participants was powerful and well received. Indeed you are a warrior forging forward in your leadership with, and for, young people.

\section{Roxanne Charlie}

The second set of speakers for day one was Chief Wayne Christian and the late Roxanne Charlie. We are sad to say that Roxanne journeyed to the Spirit World on October 31, 2009. She was 26 years old and left behind two daughters aged 2 and 4 who are now residing with relatives in Kelowna. We had the honor of meeting Roxanne Charlie in early September of this year. As shared earlier, we asked our key note speakers if they could share their speaking space with a young person and mentor them into public speaking to share their story. Chief Wayne Christian did not hesitate in his recommendation to invite Roxanne to co-speak with him. Roxanne and Wayne were the first key note speakers and spoke to an audience of almost 200 people. She was a powerful speaker, with more life experience and wisdom than many adults, let alone other young people her age.

Prior to Roxanne's arrival in Victoria for the conference, I spoke on the phone with her about her key note talk, what our expectations were and more importantly we spoke about how nervous she was. On the phone she shared about her two little girls, she spoke about returning to Kelowna and what it was like for her to live there with her little girls. Roxanne emphasized the importance for her to complete high school, to attend Nicola Valley Institute of Technology and to attend the Indigenous Governance Institute in BC. For Roxanne, it was important for her to do what she needed to sustain herself as young adult and to contribute to the wellbeing of others. For her, there were challenges and struggles she endured as a young person and her answer in life to address these challenges were to pursue higher education.

We stayed in touch over a one month period leading to the conference. Chief Wayne and another community member assisted us in providing Roxanne details about her travel to Victoria as well as assisting her in preparing for her speech. Roxanne indicated to Jacquie and Wayne that she has never spoken publicly about her story. She was nervous and cautious about what she wanted to say. Both Chief Christian and Jacquie encouraged her to share from her heart. We asked her what important message she wanted to say to young mothers, young single mothers. We encouraged her that there are many young single parents who would be encouraged in their journey by hearing her (Roxanne's) story. In the car ride from the Victoria Airport to her hotel, she shared stories about her daughters. She spoke about how beautiful her girls are and how her girls have changed her life. She was amazed at herself that during the toughest times in her life she managed to confront challenges and work through the issues. For her, it was important to address the issues not only for herself, but also for her girls. We both agreed that by sharing this story at the conference, other young single mothers would be inspired be her story. We talked about how young single parents are lonely and afraid. We encouraged Roxanne to share what inspired her to pursue education, to create a safe life for her girls and to share how she felt as a young single mom. She asked Chief Wayne and Jacquie to stand with her while she shared her story to the audience.

Roxanne's generous spirit touched the hearts and spirits of the 200 audience members who listened to her keynote presentation. Roxanne was scheduled to speak after Chief Wayne Christian, but just as Wayne was finishing his speech, she said "I can't do it." We told her it was okay and if she didn't feel comfortable sharing she didn't have to. However, once I said that, she stood up and shared her story. She shared her story to a group of social workers, academics, community members, 
Elders, other youth and students the honest in your face realities of the challenges that face young people today. She spoke about her own story with no apologies. She spoke of her pride and love for her two girls and her desire to change her life for the benefit of her little girls.

At the end of her speech, a woman in the audience stood up and asked to honor her with the Women's Warrior song. There were Elders who stood with the drummer and they asked Roxanne to stand with them. They drummed and sang to her and the audience stood up and sang as well to honor Roxanne.

After Roxanne finished her speech, people stood to clap for her and honor her life story. Some people complimented her life journey and honored her wisdom and power. Many people approached her afterwards and said their lives were changed because of the life story she shared. Because of her story, one of the participants phoned the Education Advisor at Camosun College and asked that they come meet Roxanne. The Camosun Advisor biked to the hotel and met with her to try to recruit her to college. Roxanne was thinking of going back to school. It was like the whole conference was rooting for her.

As our conference organizing team were preparing conference papers to be published in the First Nations Caring Society's on line journal, we heard the news about Roxanne's passing. Roxanne was interested in having her story published along with the other student and youth voices who shared their stories. I was working with her community worker and Chief Wayne to assist her with writing her story. What we have shared in this piece is how we remember Roxanne in the short time we had with her.

In Roxanne, we met a beautiful wise woman and devoted mother. We thank the Creator that we had an opportunity to share this last part of Roxanne's journey with her. The Steering Committee, Advisory Committee, conference participants and staff of the Indigenous Child Welfare Research Network share our condolences to Roxanne's family, friends and community.

\section{Margaret Briere}

We have known Margaret Briere for about five years. She was a student at Camosun College, she worked with young people at the Victoria Native Friendship Center she is currently a student in Child and Youth Care here at University of Victoria. Margaret has shared her experiences of been a young child in foster care. As a young girl she learned quickly how to adapt to a new home, family and community. She emerged into a wonderful young woman who now enjoys giving back to young people. Her experiences as a foster child gave her insights to work with young people today who are affected by the child welfare system. As a young person Margaret recognizes the importance of growing up around her grandparents, her territory and her traditional teachings. As a fostered child, she grew up away from these important aspects of her life. Today, Margaret recognizes the importance of grandparents, traditional territory and teachings. In her work with young people, she finds methods to teach about Indigenous traditional teachings and stories. Margaret is a young woman who expresses her excitement to life every time we see her. In the last two and half years of her educational journey, she has been very excited about learning about Indigenous knowledge, epistemology and pedagogy. These academic words are not a part of her words; however, she expresses her excitement in learning what these terms mean and how she can apply these definitions to her pursuit in higher education. Margaret has conceptualized her academic program within the context of her personal life and work experiences. In her assignments and presentations it is important for her to share the Indigenous World View. It is important to share with her classmates and other peers the importance of decolonizing our thinking and actions. Right now her goals are to complete her degree in Child and Youth Care, but we have no doubts that she will pursue $\mathrm{PhD}$ studies. Here is a little piece of what Margo shared at our conference.

My name is Margaret Briere (Margo), on my mother's side I am from the Coast Salish territory of Shishalh (Sechelt) Nation. On my father's side, he is from Nanaimo BC of European decent-French Canadian. Currently, I am attending the University of Victoria, first year and taking Child and Youth Care courses to be admitted into the program, hopefully by January 2010. My volunteer experience is extensive as I strongly value the "giving back" phenomenon stemmed from my earlier experiences as a youth who received support. Presently, I will be contributing to a decolonizing project with a group of Indigenous people facilitating at the Youth Detention Centre located in Victoria; I am also going to be working on a Harm Reduction Network Project really soon with Aids Vancouver Island organization as mentorship support with the youth. The Harm Reduction Network Project is connecting with Indigenous communities from Victoria all the way up into Port Hardy. I am super excited to be a part of that since I have previous experience in volunteering with safer practices of sex and substance use. While I will be growing in the Child and Youth Care program, I will be keeping in my mind/ spirit that I can only support someone on a journey as far I have gone. So, my perspective focuses on that as I am always learning and developing as an Indigenous woman.

Margo shared inspirational words about her work experiences and importantly about her educational journey. 
Her goal is to provide support to younger students, other young people and share with them how she managed to overcome challenges and also share how to have fun! Margo is an athlete, an activist and a wonderful role model to young people. Thank you Margo for accepting our invitation!

\section{Trevor Good}

As you have probably noticed, we have highlighted young women warriors. We want to now introduce you to Trevor Good who has completed his degree in social work, diploma from Camosun College in Indigenous Studies and is now employed as the Indigenous student advisor at the University of Victoria. Trevor highlights the important factors in his own success in post-secondary education so that others can learn from his experiences. One of key first steps for him was to address the addictions in his life and find healthy ways of dealing with stress. This shift in life for Trevor was life altering. For him, abstaining from alcohol and drugs were an essential prerequisite tor to re-learning cultural teachings and pursuing a post-secondary education. Trevor has been a wonderful support person to his peers, his family and to his large circle of friends. Here is what Trevor shared with us:

My name is Trevor Good; I am a Coast Salish man from the Snuneymuxw Nation. I grew up in different areas of Victoria. I had the honor of growing up close to Songhees and Esquimalt communities and territories. I have relatives in the Songhees and Esquimalt Nations. There were also family members from Snuneymuxw who lived in the Victoria area and I had them in my life for most of my childhood. My childhood was one filled with a blend of dysfunctional happenings and Indigenous values. My mother, a residential school survivor suffers from addictions issues. She had endured much in her childhood and did the best she could to protect my brother, sister and me from the intergenerational trauma she/we process. This is an impossible task for anyone to carry out; as a result my childhood was traumatic, dysfunctional at the worst of times and calm at the best of times. As I entered my teen age years I quickly became familiar with my own addictions. I walked down that black road for all of my teens; as a result I did very poorly in school. I failed the majority of my classes but learned to work my way up the grade ladder by using flaws in the educational system.

As I stumbled into my twenties my addictions were out of control. At 24 I knew I needed a change and at the age 25 I checked myself into Round Lake Treatment Centre. It was here I was introduced to Indigenous teachings and reintroduced to my own Nations teachings. In Round Lake I was shown teachings that would allow me to build a foundation for walking the Red Road and continue to grow as an Indigenous person.

A few months after leaving Round Lake I started upgrading at the Songhees Band School. After many previous unsuccessful attempts to other upgrading schools, the Songhees school was a safe place to learn and begin my educational journey. I was learning in and with community and that created a bridge to work my way into Camosun College where I finished my upgrading and entered the Indigenous Studies program which is a two year diploma program. During my time at Camosun I had the opportunity to apply for a summer job at the Victoria Native Friendship Centre. The job was working with Indigenous youth. At the end of the summer another job had came up and another, I found myself there for nearly two years under three different positions. During this time I found myself applying and being accepted to the University of Victoria, into the Bachelor of Social Work (Indigenous specialization) program. The feeling was surreal to me; I could not believe how far I had come in such a short time. I have heard many community members tell me to "walk in a good way" and in doing amazing opportunities have been presented in my path. For example, I was able to travel to Australia for the World Indigenous Education conference in Melbourne, Australia. I also spent a week in New Zealand, Whatake at University of Te Whare Wananga o Awanuiarangi for six nights.

Every summer for the past six years the Office of Indigenous Affairs, here at the University of Victoria hosts a mini Indigenous youth summer camp. I had the opportunity to volunteer two summers in a row and at the end of the second time of volunteering, I was finishing the social work degree, a job was opening up within the Office of Indigenous Affairs. I applied for it and was successful and now I am currently the Coordinator of Indigenous student support. My job is great and I am able to be around wonderful people daily. I have been given so many great gifts and am grateful for all I have; many remarkable people along the way have reminded me to be aware that I have the responsibility and an advantage of staying connected and working for our Indigenous communities. I truly learning and meeting new people every day! Hychqa Siem!

This young man certainly is a role model for other young men. He has committed himself to continuously re-learning and un-learning the world view of Snuneymuxw people and cultures. As in his story, he continuously pursues aspects that will enrich his life personally and professionally. Trevor's goals are to attend grad school and we are all sure that in the future he will become a Professor in a university setting. 
First Peoples Child \& Family Review, Volume 5, Number 1, 2010

\section{Conclusion}

These are the students and young people who are interested in having their story published. As a reviewer of student and youth voices we have not changed their words, we only changed explicit corrections when necessary. There were other young people, as well as other presenters who contributed to our knowledge sharing and gathering during the two days who chose not to have their presentation published. We thank you for sharing your knowledge and for assisting us to make our conference a success.

There were a mixture of young people, adults, professionals, community members and Elders listening to all the stories shared. The conference provided for people the opportunity to network with one another and to broaden relationships to enrich the lives of young people, their families and their communities.

In two years our goal for a second conference is to invite our International Indigenous partners to share about their methods for nurturing their communities and families. The first year of our network came with much enthusiasm from our staff, governing body and network membership to look at alternative ways to care for our children. An over-arching theme from our conference was to regenerate our traditional teachings and stories and implement them into our diverse practices and professions. As a network, it is our goal to broaden our membership, continue to share and gather stories and teachings that are leaving a positive impact for our families.

Wa!

Hychqa

Quayana

Gilakas, la 